\title{
Population Structure of Greenland Halibut (Reinhardtius hippoglossoides) in the Northeast Arctic, 1992-2000
}

\author{
Åge Sigurd Høines and Knut Korsbrekke \\ Institute of Marine Research, P.O. Box 1870 Nordnes \\ N-5817 Bergen, Norway
}

\begin{abstract}
The variation in population structure of Greenland halibut (Reinhardtius hippoglossoides Walbaum) in the Northeast Arctic is analysed using data from three different surveys using trawl, longline and gillnet gears, in the slope area of the western Barents Sea in the period 1992-2000. The design of the longline and gillnet survey had limitations in that they were set to simulate the commercial fisheries, but the vessels were forced to cover the most important part of the slope area. Greenland halibut was the dominant species both in numbers and weight and was usually caught in the range of 5-15 years old, but the catch was dominated by ages 6-12. The data showed differences in sex composition and age composition both by area and by depth, and catches from trawl showed the most evident pattern. Greenland halibut caught by gillnet were larger and older than fish caught by trawl and the results from longline were in between. In most of the age groups, males were significantly smaller than females and this general trend was shown for all gears. Males also dominated the younger age groups in all gears and Greenland halibut older than 10 years were virtually all females. Fish from the earliest cohorts in the years investigated were generally smaller than fish from later ones.
\end{abstract}

Key words: ANOVA, gillnet, Greenland halibut, longline, Northeast Atlantic, trawl

\section{Introduction}

Greenland halibut (Reinhardtius hippoglossoides, Walbaum) is distributed in the Arctic and boreal waters in the North Atlantic and in the North Pacific (Fedorov, 1971; Godø and Haug, 1989; Bowering and Brodie, 1995; Bowering and Nedreaas, 2000). In the northeastern Atlantic the distribution is more or less continuous along the continental slope from the Faeroe Islands and Shetland to north of Spitsbergen (Whitehead et al., 1986; Godø and Haug, 1989), with the highest concentrations from 500 to $800 \mathrm{~m}$ depth between Norway and Bear Island, which is also regarded as the main spawning area (Godø and Haug, 1987; Albert et al., 2001b). Peak spawning occurs in December in the main spawning area, but also in nearby localities during summer (Albert et al., 2001b). Eggs and larvae drift northwards and the juveniles are distributed in the deeper parts of the Barents Sea and to the north and east of Spitsbergen, to the waters around Franz Josef Land (Godø and Haug, 1987; 1989; Albert et al., 2001a).

Before the mid-1960s, the fishery for Greenland halibut in the Northeast Arctic was mainly a coastal longline fishery off the coasts of eastern Finnmark and Vesterålen in Norway. Following the introduction of international trawlers in the fishery in the mid1960 s, the total landings increased from a level of about 3000 tons to about 80000 tons in the early1970 s. The total landings decreased steadily to a level of about 20000 tons during the early-1980s (ICES, MS 2001). The commercial trawl fishery was concentrated in the main distribution area for the adult stock. Based on the regular 0-group survey in the Barents Sea, a drop in the year-class indices were observed during the late-1980s and beginning of the 1990s, and also a historic low spawning stock biomass was detected in the same period (Hylen and Nedreaas, 1995; Smirnov, 1995). There was also a reduction in the commercial catch per unit of effort (CPUE) and this led to strong regulations starting in 1992, including a total fishing ban for Greenland halibut north of $71^{\circ} 30 \mathrm{~N}$. South of this limit the regulation rules allowed only a limited longline and gillnet fishery, by vessels smaller than $28 \mathrm{~m}$, to be directed for Greenland halibut. Trawl catches were limited to by-catch only (Bowering and Nedreaas, 2000).

When the catches from the commercial fishery declined after 1992, it became very important to increase the research effort in order to confirm or in- 
validate the perceived reduction in recruitment and the decrease in spawning stock. To continue the already established time series of commercial trawl CPUE data and to improve biological sampling as a basis for stock assessment, commercial fishing vessels were contracted. The vessels performed commercial-scale fishing, but restricted to certain time periods and areas. The gears used were trawl, longlines and gillnets. In 1994, a scientific bottom trawl survey started in the slope area from $68^{\circ} \mathrm{N}$ to $80^{\circ} \mathrm{N}$.

Based on a stratified trawl survey in the Svalbard area, Godø and Haug (1987) documented that depth distribution of Greenland halibut was size dependent, i.e. higher proportions of large fish were found in deeper strata. The same investigation concluded also that north of $76^{\circ} \mathrm{N}$ the stock consisted of a relatively higher proportion of small fish. The structure of the catch, i.e. length, age and sex composition changes with different gear. Longline and gillnet catch larger fish than trawl (Nedreaas et al., 1996). The present study therefore used data from all three gear types with the objective to describe how the population structure of the Greenland halibut stock varied between years, areas and gears along the slope area between Norway and Svalbard in the period 19922000 .

\section{Material and Methods}

\section{Surveys and sampling}

Data were collected during several surveys between Norway and Svalbard in autumn in the period 1992-2000 (Table 1, Fig. 1). Some of the trawl surveys were designed as a stratified bottom trawl survey with Greenland halibut as target species, but all the longline and gillnet surveys were set up in a way attempting to mimic the commercial Greenland halibut fishery. Commercial fishing vessels were contracted to conduct regular fishing operations, but there were some restrictions in the area where they were able to operate, i.e. between $70^{\circ} \mathrm{N}$ and $76^{\circ} \mathrm{N}$. The scientific bottom trawl survey operated in a wider area, $68^{\circ} \mathrm{N}-80^{\circ} \mathrm{N}$, with fixed positions of the hauls in a depth range of 400 to $1500 \mathrm{~m}$. Due to the expectation of low catches deeper than $1000 \mathrm{~m}$, very few hauls were carried out at these depths. The survey series, with exception of longline and gillnet, have been evaluated and used in the Arctic Fisheries Working Group in ICES as tuning series in the Greenland halibut assessment (ICES, MS 2001). In addition some publications have used parts of the available data from the time series analyzing selectivity, fecundity and distribution of Greenland halibut (i.e. Nedreaas et al., 1996; Huse et al., 1999; Gundersen et al., 1999; Bowering and Nedreaas, 2000).

The trawlers used standard cod bottom trawls (Alfredo 5) with $135 \mathrm{~mm}$ mesh width (inside stretched mesh), and a $60 \mathrm{~mm}$ inner lining in the codend. The vertical opening of the trawl was about $4 \mathrm{~m}$ and the distance between the doors averaged to $170-175 \mathrm{~m}$. The trawls were equipped with rock-hopper gear. The length of the ground gear was approx. $110 \mathrm{~m}$ and the lengths of the sweeps were $130-140 \mathrm{~m}$. The warp length under towing was 2.5-2.8 times the bottom depth depending on current and bottom conditions. Towing speed was 4 knots and the towing duration in the "commercial" experiments were normally 4-5 hours. Towing duration in the bottom trawl survey was usually one hour.

The longliners used in most cases Mustad EZbaiter hooks no. 12 with hook spacing of $1.4 \mathrm{~m}$. During the time period each setting varied between 3000 and 6000 hooks. The hooks were baited mechanically (Mustad Autoline System) mostly with sequences of squid and mackerel, but also other bait types were used occasionally. The soak time varied between 6 and 24 hours. Each setting was treated as one separate station.

The gillnets were made of monofilament with a varying mesh size from 70 to $110 \mathrm{~mm}$ (bar-length, i.e. 140-220 $\mathrm{mm}$ stretched mesh), but most of the settings were made with $110 \mathrm{~mm}$ bar-length, which is most often used in the commercial fishery. The proportion of different mesh sizes was constant between years. Each setting consisted of 30 nets each $30 \mathrm{~m}$ long, tied end to end in a fleet. The height of the nets was 20 meshes, and the hanging ratio $60 \%$. The fleets were bottom-set, anchored to the bottom at one end only, letting the other end drift freely with the current. The soak time varied from 50 to 140 hours and each fleet was treated as one separate station.

The procedure for collecting individual samples was unfortunately not consistent throughout the timeseries, but individual samples, when collected, were stratified both geographically and by depth. The inconsistency in sampling caused problems getting enough samples from different gears in some of the years, but for most of the years weight and numbers of Greenland halibut for each separate station were recorded. Total length-frequency distributions (to the nearest $\mathrm{cm}$ below) were obtained, either by measur- 
TABLE 1. List of surveys from which data for this paper were collected. Number of samples by gear, $\mathrm{N}$ denotes number of stations, $N_{L}$ is number of stations with length samples and $N_{A}$ is number of stations with age sampling.

\begin{tabular}{|c|c|c|c|c|c|}
\hline Year & Gear type & Time period & $N$ & $N_{L}$ & $N_{A}$ \\
\hline \multirow[t]{3}{*}{1992} & Trawl & $6.10-21.10$ & 108 & 107 & 41 \\
\hline & Longline & $5.10-21.10$ & 85 & 84 & 28 \\
\hline & Gillnet & $9.10-21.10$ & 120 & 120 & 30 \\
\hline \multirow[t]{3}{*}{1993} & Trawl & $10.10-23.10$ & 56 & 53 & 19 \\
\hline & Longline & $7.10-16.10$ & 41 & 40 & 15 \\
\hline & Gillnet & $7.10-20.10$ & 235 & 234 & 52 \\
\hline \multirow[t]{3}{*}{1994} & Trawl & $13.9-30.9$ & 34 & 34 & 16 \\
\hline & Longline & $27.9-8.10$ & 71 & 49 & 8 \\
\hline & Gillnet & $27.9-11.10$ & 130 & 126 & 13 \\
\hline \multirow[t]{3}{*}{1995} & Trawl & $16.8-7.9$ & 38 & 38 & 11 \\
\hline & Longline & $22.9-3.10$ & 58 & 41 & 4 \\
\hline & Gillnet & $22.9-5.10$ & 88 & 69 & 8 \\
\hline \multirow[t]{3}{*}{1996} & Trawl & $2.8-23.8$ & 38 & 38 & 7 \\
\hline & Longline & $17.9-27.9$ & 43 & 26 & 3 \\
\hline & Gillnet & $19.9-26.9$ & 46 & 43 & 9 \\
\hline \multirow[t]{3}{*}{1997} & Trawl & $2.8-21.8$ & 47 & 47 & 7 \\
\hline & Longline & $17.9-29.9$ & 67 & 34 & 0 \\
\hline & Gillnet & $21.9-30.9$ & 42 & 29 & 0 \\
\hline \multirow[t]{3}{*}{1998} & Trawl & $2.8-25.8$ & 55 & 55 & 6 \\
\hline & Longline & $21.9-1.10$ & 58 & 27 & 3 \\
\hline & Gillnet & $19.9-29.9$ & 26 & 25 & 2 \\
\hline \multirow[t]{3}{*}{1999} & Trawl & $2.8-21.8$ & 46 & 46 & 4 \\
\hline & Longline & $21.9-5.10$ & 64 & 27 & 8 \\
\hline & Gillnet & $23.9-1.10$ & 32 & 28 & 11 \\
\hline \multirow[t]{3}{*}{2000} & Trawl & $31.7-20.8$ & 53 & 53 & 5 \\
\hline & Longline & $21.9-3.10$ & 42 & 19 & 6 \\
\hline & Gillnet & $19.9-28.9$ & 33 & 31 & $16^{1}$ \\
\hline
\end{tabular}

${ }^{1}$ Data not available for analysis.

ing the entire catch or from a random subsample. In some stations individual length and weight were recorded, stratified to 5 individuals of each sex in $5 \mathrm{~cm}$ length groups. From these fish the otoliths were collected for age determination at a later stage in laboratory. The procedure used for age determination is described in Bowering and Nedreaas (2001). In addition, the individually sampled fish were classified to maturity stage using a general description for macroscopic determination of maturity stage (Table 2). Only stages 2-4 were used in the analyses as mature fish.

\section{Analyses}

Different population characteristics and structures were studied using three different models. The first model used age as the dependent variable and related age in catch to year, sex, area and depth using a traditional analysis of variance (ANOVA).

$$
A G E=Y E A R+S E X+A R E A+D E P T H
$$

This model is predicting the mean age in a catch by sex given year area and depth interval. In addition 


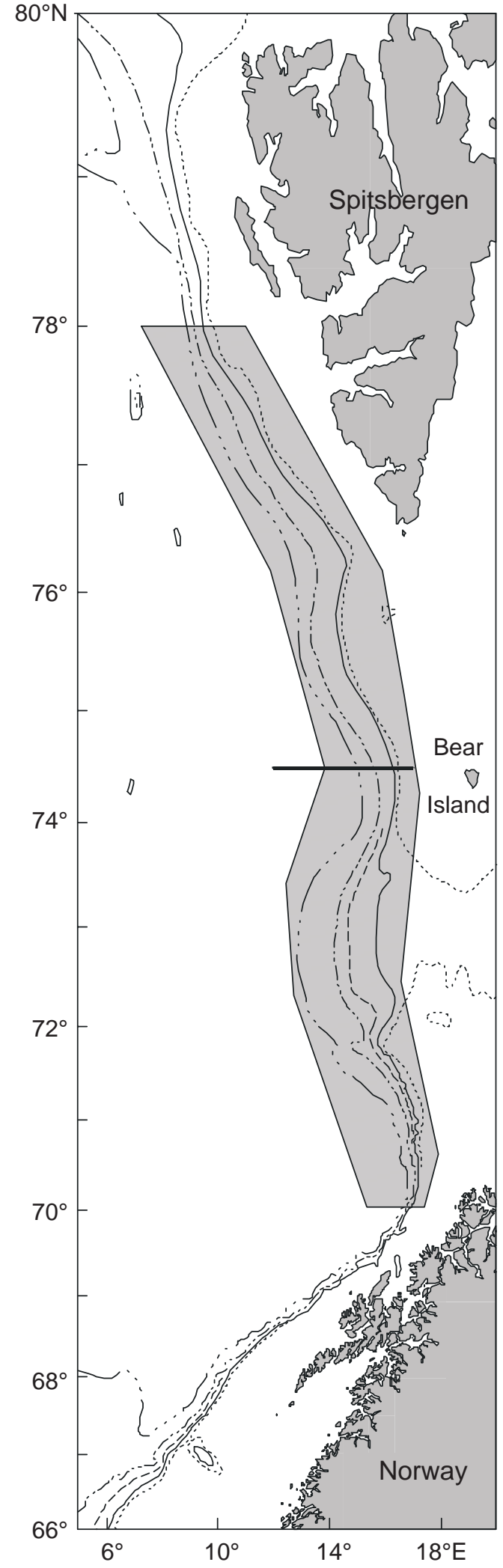

Fig. 1. Experimental area (shaded), with depth contours 400, 500, 700, 1000 and $1500 \mathrm{~m}$ drawn. The horizontal line is the geographic division used in the paper. to the intercept, up to nine-year effect parameters were estimated (1992-2000). Due to the lack of unique solutions, the last year parameter was not really estimated, but set to zero. The sex and area effect had two levels each, while the depth effect had two or three levels. This was because age was sampled in three different depth intervals $(400-500,500-600$ and $600-700 \mathrm{~m}$ ) in the longline survey, but only in two intervals $(400-500$ and $500-600 \mathrm{~m})$ in the gill-net survey and (500-600 and 600-700 m) in the trawl survey.

The second model had length as the dependent variable explained by age, cohort, sex and maturity (both interacting with age) and depth.

$$
\begin{gathered}
L E N G T H=A G E+C O H O R T+A G E * S E X \\
+A G E * M A T U R I T Y+D E P T H
\end{gathered}
$$

The importance of sex in the two first models led us to look at a third model which used age, depth and area as explanatory variables for the proportion females. The proportion females $P_{\text {females }}$ was modelled using a logistic regression:

$$
\operatorname{LOGIT}\left(P_{\text {females }}\right)=A G E+A R E A+D E P T H
$$

One age parameter for each age group (ages 512), two areas and two or three depth intervals. The model was checked for over-dispersion and if the model showed a significant lack of fit the covariance matrix was rescaled. Note that the parameter estimates are not changed by this method. However, their standard errors are adjusted affecting their significance tests.

\section{Results}

Comparison of mean age in the catches revealed a relatively clear pattern, i.e. the mean age of Greenland halibut caught in different gears were not the same. Gillnet caught the oldest fish and trawl the youngest. Fish caught with longline had a mean age between gillnet and trawl (Fig. 2). The model predicting fish age exposed some differences between gears, but only catches from trawl revealed significant differences by all effects investigated (i.e. year, sex, area and depth; Table 3). Longline and gillnet showed a significant difference in mean age only by sex, year and area, and sex and year, respectively.

The length distributions of Greenland halibut in the catches from the different gear types showed some variability throughout the period, but they were relatively stable within gillnet and longline surveys. In 
TABLE 2. Definition of the macroscopic determination of maturity stages of Greenland halibut used at sea.

\begin{tabular}{|c|c|}
\hline Stage & Description \\
\hline Blank & Undecided/not checked \\
\hline 1 & Immature Gonads are small. No visible eggs or milt. \\
\hline 2 & Maturing Gonads are larger in volume. Eggs or milt are visible but not running. \\
\hline 3 & Spawning Running gonads. Light pressure on the abdomen will release eggs or milt. \\
\hline 4 & $\begin{array}{l}\text { Spent/Resting Gonads small, loose and/or bloody. Regeneration starting, gonads somewhat } \\
\text { larger and fuller than stage } 1 \text {. No visible eggs or milt. }\end{array}$ \\
\hline 5 & Uncertain Use only when difficult to distinguish stages 1 and 4. \\
\hline
\end{tabular}

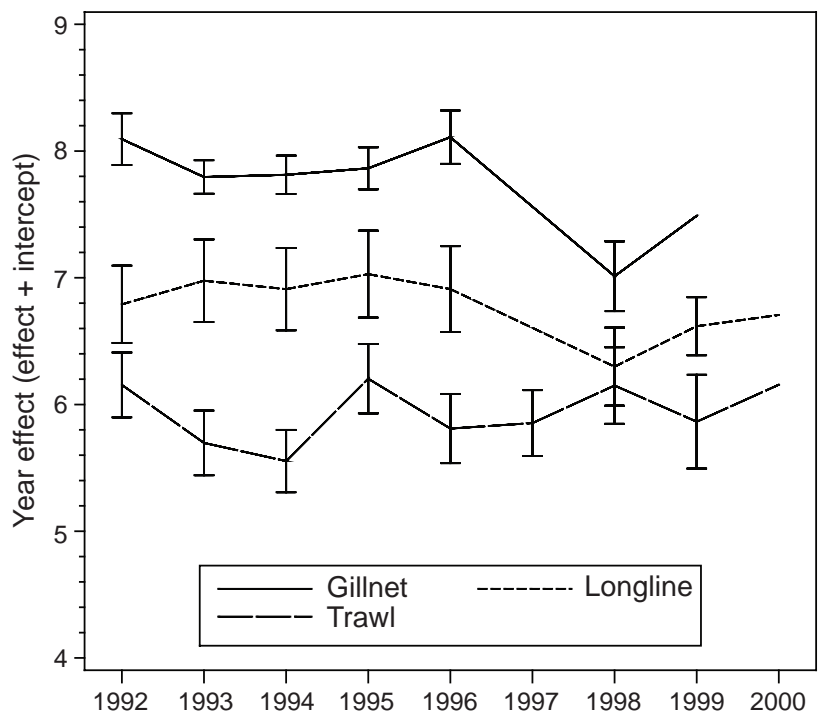

Fig. 2. Trends in mean age in catches of Greenland halibut in the period 1992-2000.

TABLE 3. Type III analyses of effects for the models predicting fish age.

\begin{tabular}{|c|c|c|c|c|c|c|c|}
\hline Model & $R^{2}$ & Effect & $d f$ & Type III SS & MS & F Value & $P$ \\
\hline \multirow{4}{*}{ Longline } & 0.5143 & Year & 7 & 6.4098 & 0.916 & 3.39 & 0.0013 \\
\hline & & Sex & 1 & 608.90 & 608.9 & 2256.6 & $<0.0001$ \\
\hline & & Area & 1 & 9.0322 & 9.032 & 33.47 & $<0.0001$ \\
\hline & & Depth & 2 & 0.7078 & 0.354 & 1.31 & 0.2695 \\
\hline \multirow[t]{4}{*}{ Gillnet } & 0.3953 & Year & 6 & 59.831 & 9.972 & 17.07 & $<0.0001$ \\
\hline & & Sex & 1 & 660.08 & 660.1 & 1130.1 & $<0.0001$ \\
\hline & & Area & 1 & 0.0345 & 0.035 & 0.06 & 0.8081 \\
\hline & & Depth & 1 & 0.6120 & 0.612 & 1.05 & 0.3062 \\
\hline \multirow[t]{4}{*}{ Trawl } & 0.2076 & Year & 8 & 1668.8 & 208.6 & 11.63 & $<0.0001$ \\
\hline & & Sex & 1 & 8467.0 & 8467 & 471.85 & $<0.0001$ \\
\hline & & Area & 1 & 718.25 & 718.2 & 40.03 & $<0.0001$ \\
\hline & & Depth & 1 & 2506.8 & 2506 & 139.70 & $<0.0001$ \\
\hline
\end{tabular}



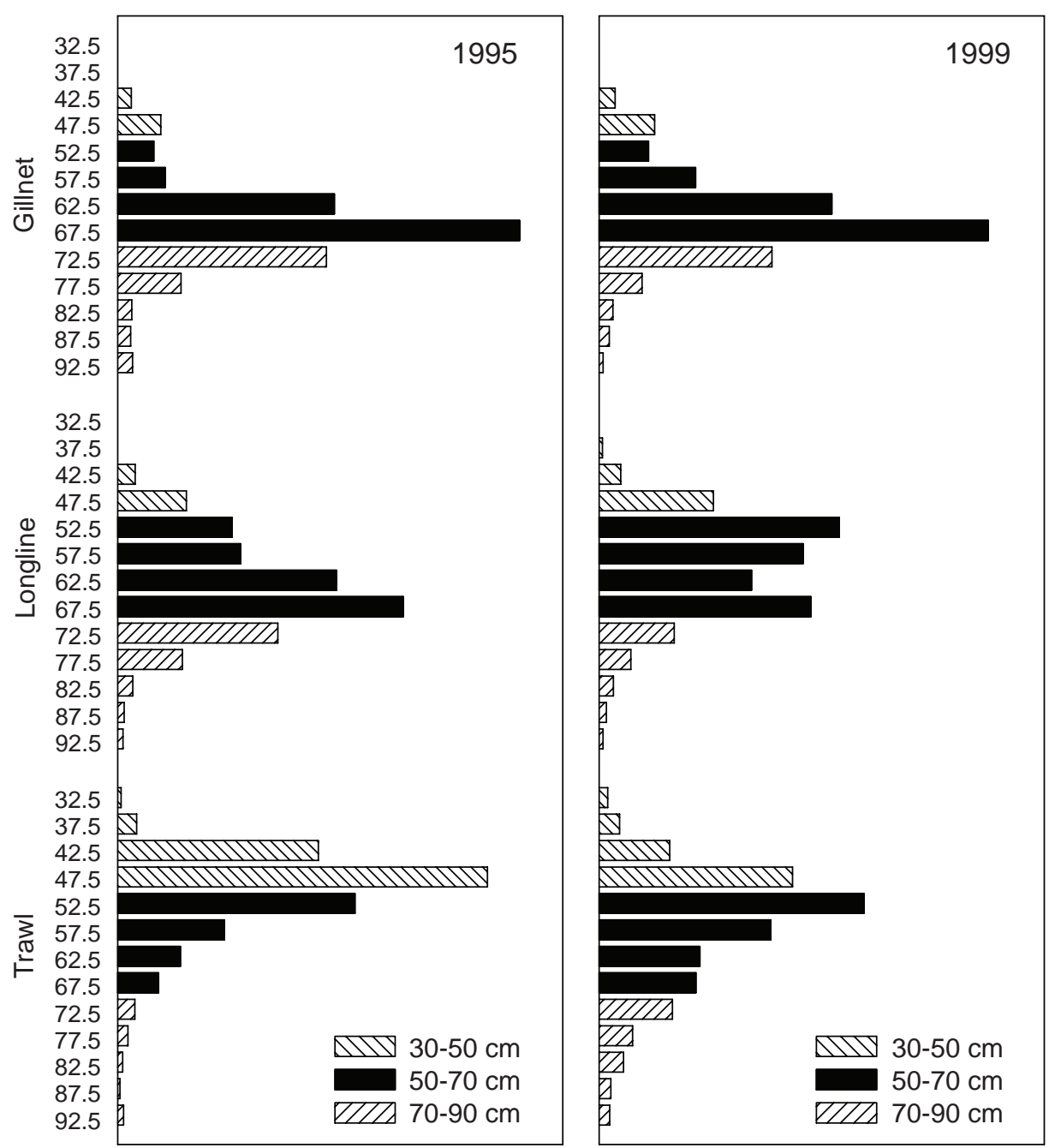

Fig. 3. Length distributions from catches of Greenland halibut in gillnet, longline and trawl in 1995 and 1999. All distributions are scaled to a fixed catch to enable comparison of size composition.

the trawl catches the length increased during the period, with relatively small changes from year to year. The length distributions from the years 1995 and 1999 are shown since these years are the most extreme years (Fig. 3). The modal lengths of fish caught in gillnet and longline was generally $15-20 \mathrm{~cm}$ larger than fish caught in trawl. The estimated age parameters in the length model (length at age) showed that the different gears caught fish of the same size at age (Fig. 4). Fish caught in gillnet showed slightly lower $\mathrm{R}^{2}$, with no clear reason. No difference in the mean length by depth was found in catches from gillnet and longline, but in trawl catches the depth effect was significant (Table 4).
The length of Greenland halibut showed an increasing trend from the 1980 year-class to the yearclasses in the beginning of 1990 s, i.e. fish from the earliest cohorts in the years investigated were generally smaller than fish from later ones (Fig. 5). Even if there were few observations for the first and the latest years, the cohort effect was significant in all gears (Table 4).

In most age groups males were significantly smaller than females (Fig. 6, Table 4). The trend increased with age (i.e. the difference between the sexes became larger with older ages), but in the oldest age groups the numbers of observations were few and this 

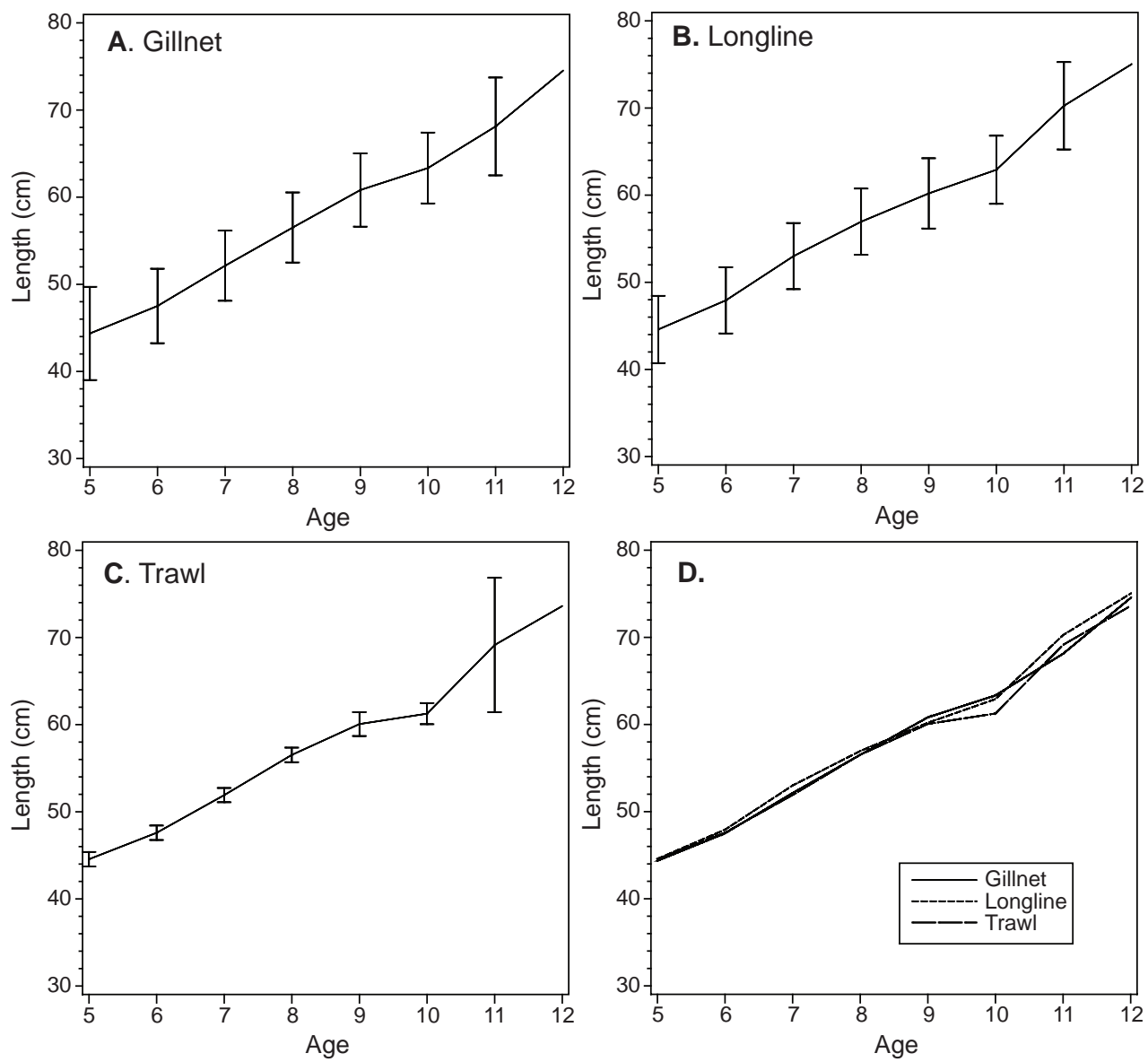

Fig. 4. Estimated age parameters (age effect) with error bars ( $\pm 2 \mathrm{SD})$ in catches of Greenland halibut from gillnet, longline and trawl. Parameter estimates for all models shown in D).

could be the cause for an unexpected change in this pattern. For these age groups the size of males and females were not different or the males were larger, but in these observations females were highly dominant. The general trend was shown for all gears.

Immature Greenland halibut were smaller than the mature with exception of the youngest age group (Fig. 7), and the difference was significant in catches from all gears (Table 4).

Generally males dominated the younger age groups in all gears and Greenland halibut older than 10 years were virtually all females (Fig. 8, Table 5). The youngest age group from gillnet ( 5 year old) was different from the others, showing higher proportion of females in the different strata. In catches from longline, the area and depth difference was not significant, i.e. corresponding proportions of females were found both north and south of $74^{\circ} 30^{\prime} \mathrm{N}$ and in all depth strata. The trawl caught a larger proportion of females in the north, and catches from the depth stratum between 500 and $600 \mathrm{~m}$ also had higher a proportion of females both in the north and south.

\section{Discussion}

The analyses of the three survey series from the slope area between Norway and Spitsbergen expressed a more homogenous pattern in the investigated population parameters than expected, but still there were some differences. Earlier work in the same area has demonstrated that there are patterns in size, and thus age, distribution along the slope. Polish investigations stated in 1973 that Greenland halibut west of Spitsbergen were smaller than individuals further south (Kosior, 1975). This was also observed on Norwegian groundfish surveys in early 1980s (Randa and Smestad, MS 1982; MS 1983; Godø et al., MS 1984), but all these surveys compared fish from a wider 

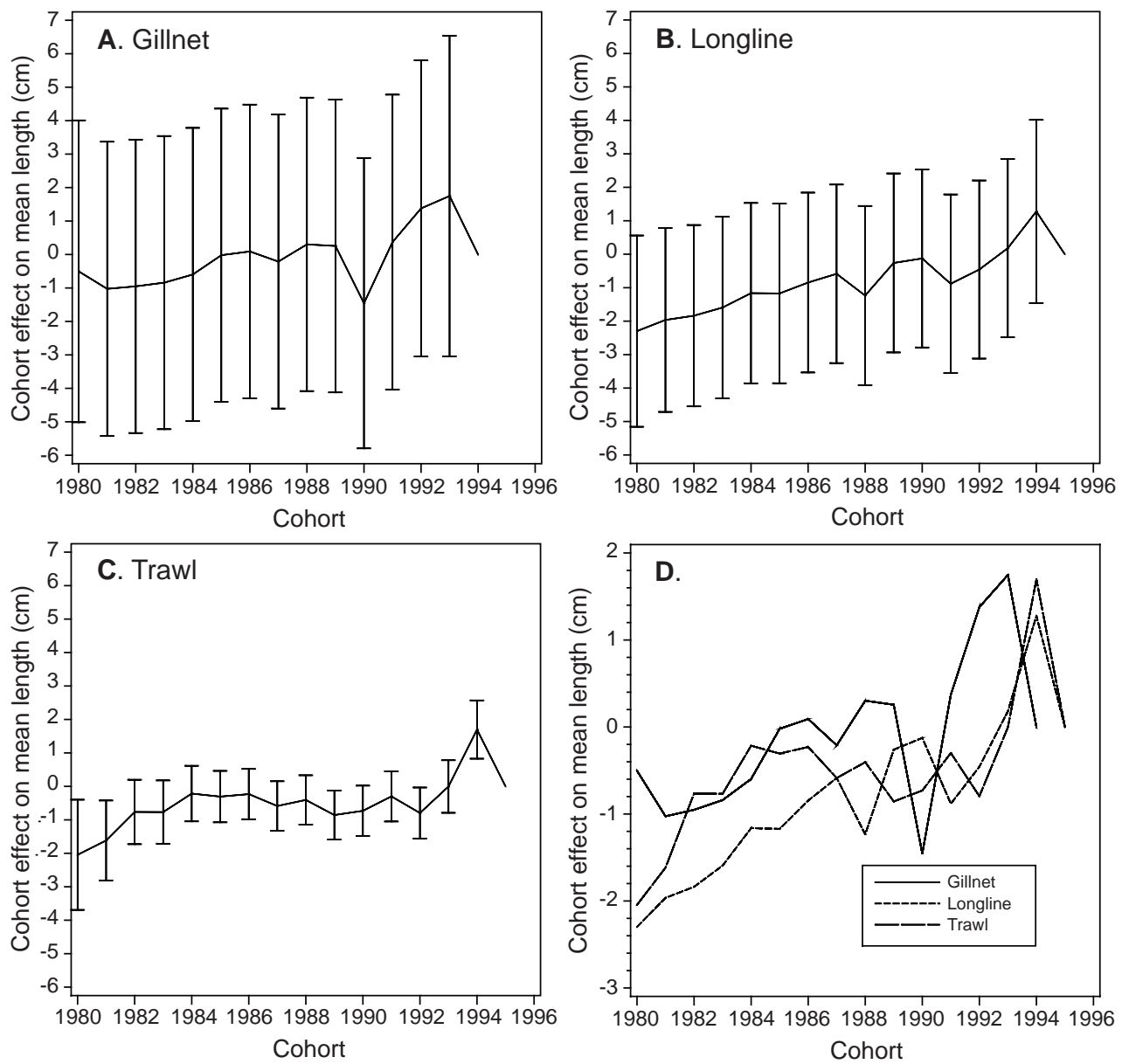

Fig. 5. Estimated cohort parameters (cohort effect) with error bars ( $\pm 2 \mathrm{SD})$ in the length models. Parameter estimates for all models shown in D).

survey area than our investigation. In the beginning of the 1990s, the limited fishery for Greenland halibut was only allowed south of $71^{\circ} 30^{\prime} \mathrm{N}$ and the commercial fisheries organizations expressed concern about the stock status in the whole distributional area. The only information on the Greenland halibut stock further north was from the scientific surveys conducted in that area. From 1992, i.e. after implementation of the strong regulations of the Greenland halibut fishery, it was decided to prolong the trawl CPUEseries with an experimental trawl series, and in addition, to meet the request from the fisheries organizations it was decided to start an experimental fishery with longline and gillnet in the area from $71^{\circ} \mathrm{N}$ to $76^{\circ} \mathrm{N}$. These experimental surveys were highly motivated by the fishermen themselves and they were carried out like a "fisherman's choice" on where to put their effort. Hence, there have been changes in area and depth coverage throughout the time series caus- ing problems with the consistency and the sampling regime of these data series. Most effort was carried out in clusters north and south of a natural boundary around $74^{\circ} 30^{\prime} \mathrm{N}$, covering an area which is known as the main area for the adult (mature) stock (Godø and Haug, 1987; 1989; Albert et al., 2001b). The Greenland halibut trawl survey has been a scientific fixedstation survey covering a wider area and also a wider depth gradient, i.e. a more homogenous coverage along the whole slope area during the whole time period investigated. The result of this has probably been a better coverage of the adult Greenland halibut stock in the area. The results also reflect this since the analyses showed the highest variability in the population parameters investigated in the catches from this data series.

The selection properties of the different gear types were quite different from each other, especially for 

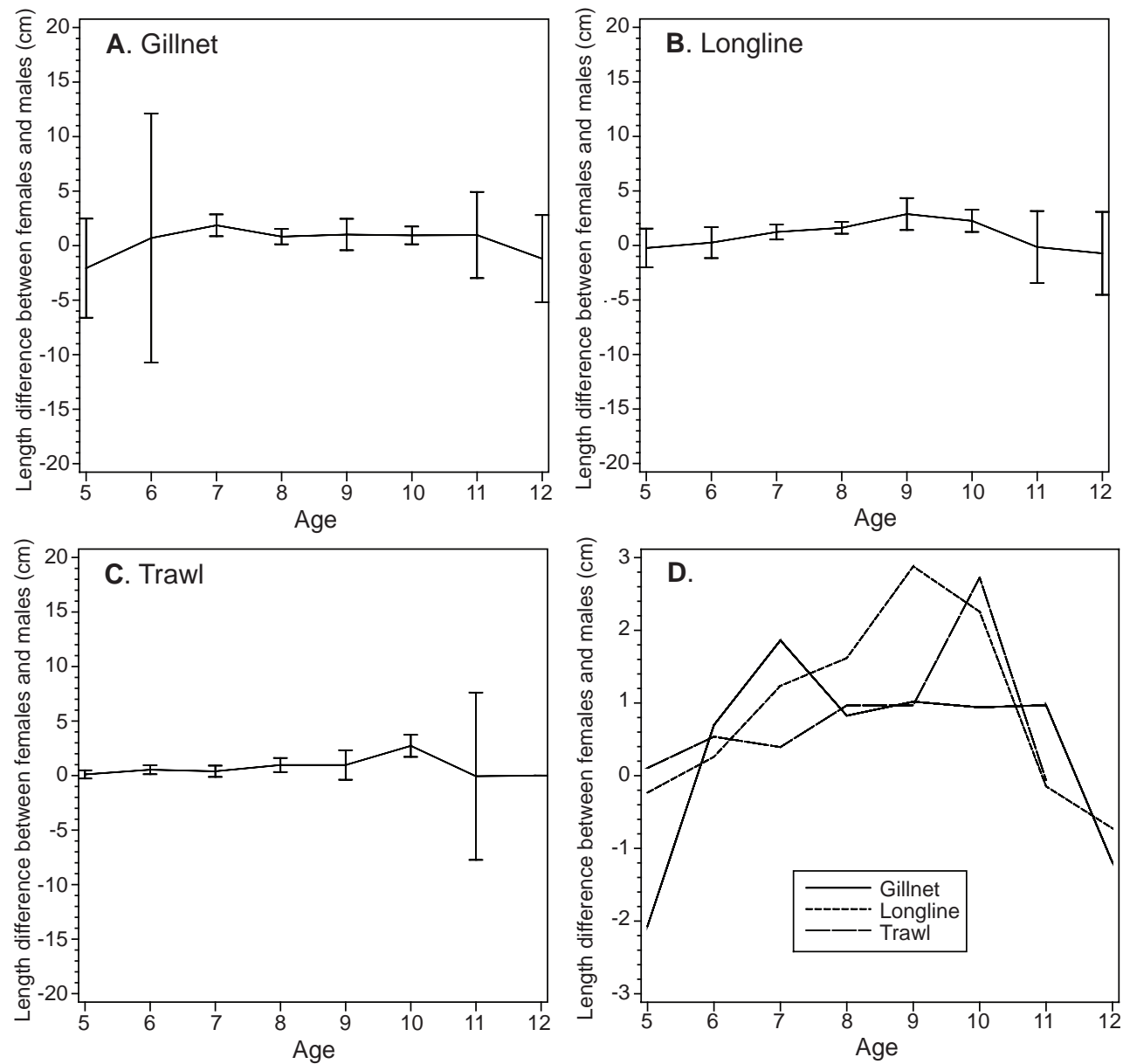

Fig. 6. Estimated interaction between sex and age, with error bars $( \pm 2 \mathrm{SD})$. The lines represent the difference in length between females and males at different age groups. Parameter estimates for all models shown in D).

TABLE 4. Type III analyses of effects for the models predicting fish length.

\begin{tabular}{|c|c|c|c|c|c|c|c|}
\hline Model & $R^{2}$ & Effect & $d f$ & Type III SS & MS & $F$ Value & $P$ \\
\hline \multirow[t]{5}{*}{ Longline } & 0.9246 & Cohort & 15 & 66.836 & 4.456 & 6.05 & $<0.0001$ \\
\hline & & Age & 7 & 2339.8 & 334.2 & 453.85 & $<0.0001$ \\
\hline & & Age $\times$ Sex & 8 & 61.735 & 7.717 & 10.48 & $<0.0001$ \\
\hline & & Age $\times$ Maturity & 8 & 57.644 & 7.206 & 9.78 & $<0.0001$ \\
\hline & & Depth & 2 & 2.8472 & 1.424 & 1.93 & 0.1449 \\
\hline \multirow[t]{5}{*}{ Gillnet } & 0.8767 & Cohort & 14 & 261.78 & 18.70 & 8.77 & $<0.0001$ \\
\hline & & Age & 7 & 2187.2 & 312.5 & 146.55 & $<0.0001$ \\
\hline & & Age $\times$ Sex & 8 & 59.993 & 7.499 & 3.52 & 0.0005 \\
\hline & & Age $\times$ Maturity & 8 & 135.21 & 16.90 & 7.93 & $<0.0001$ \\
\hline & & Depth & 1 & 0.5074 & 0.507 & 0.24 & 0.6257 \\
\hline \multirow[t]{5}{*}{ Trawl } & 0.9299 & Cohort & 15 & 4135.6 & 275.7 & 9.44 & $<0.0001$ \\
\hline & & Age & 7 & 288092 & 41156 & 1409.68 & $<0.0001$ \\
\hline & & Age $\times$ Sex & 7 & 1433.2 & 204.7 & 7.01 & $<0.0001$ \\
\hline & & Age $\times$ Maturity & 8 & 3205.9 & 400.7 & 13.73 & $<0.0001$ \\
\hline & & Depth & 1 & 977.84 & 977.8 & 33.49 & $<0.0001$ \\
\hline
\end{tabular}



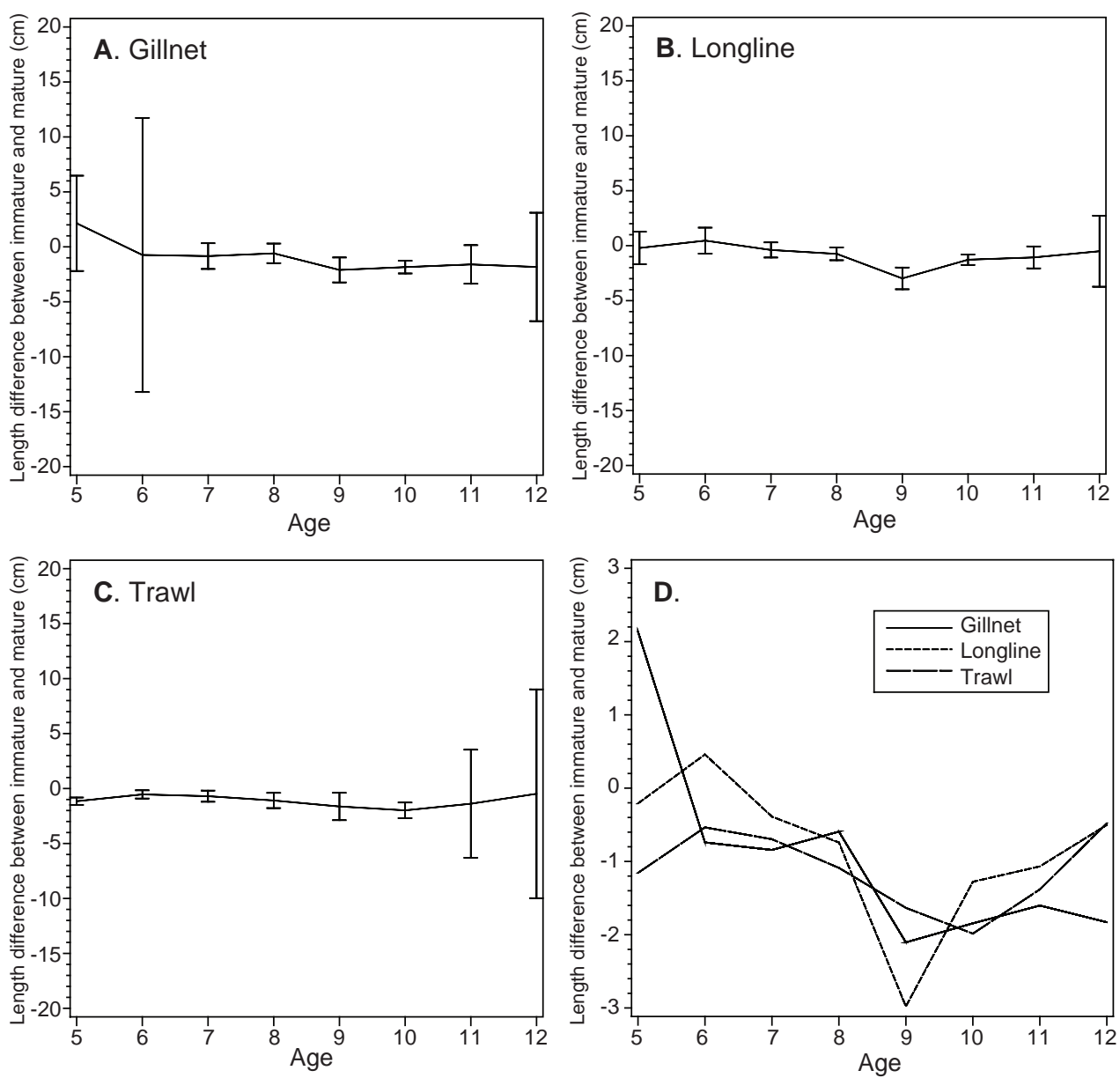

Fig. 7. Estimated interaction between maturity and age, with error bars $( \pm 2 \mathrm{SD})$. The lines represent the difference in length between immature and mature fish at different age groups. Parameter estimates for all models shown in D).

the trawl. Trawl catches had a wider size spectrum than catches from gillnets and longlines and also caught more fish of smaller sizes. The differences between gillnet and trawl catches may be explained by the mesh selection properties of the gillnet (Nedreaas et al., 1996) and that the trawl is an active gear catching more or less all in its path. The trawls may better reflect the true size composition in the stock, but the catch is also affected by avoidance reactions to the approaching gear, which may bias the length frequency composition in these catches (Ona and Godø, 1990). This factor is probably most important for the largest individuals causing the trawl catches to be dominated by relatively smaller fish. The selection properties of longlines are dependent on several factors including feeding behavior or feeding motivation, and the hook's ability to catch different groups of fish. Another important factor in longline catches is the competition between species and size groups of species and their different swimming range and speed. It is probable that the largest and fastest fish are approaching the baited hooks first, i.e. hooking the larger ones in the area, which again increases the mean size of fish caught on longlines.

Some differences were found in all gears used, and, as mentioned previously, trawl data showed that there were significant area, depth, length, age and sex effects. Greenland halibut caught in trawls showed that there were significant difference in length and age by depth, i.e. suggesting size segregation of the individuals by depth. The largest fish was found in intermediate depths below $550 \mathrm{~m}$ depth, but smaller fish appeared at greater depths. This pattern was not confirmed by gillnets and the reason for this is that gillnets were set in a more narrow depth interval, which did not reveal the difference in size by depth. Even if the difference was not significant for longlines, 

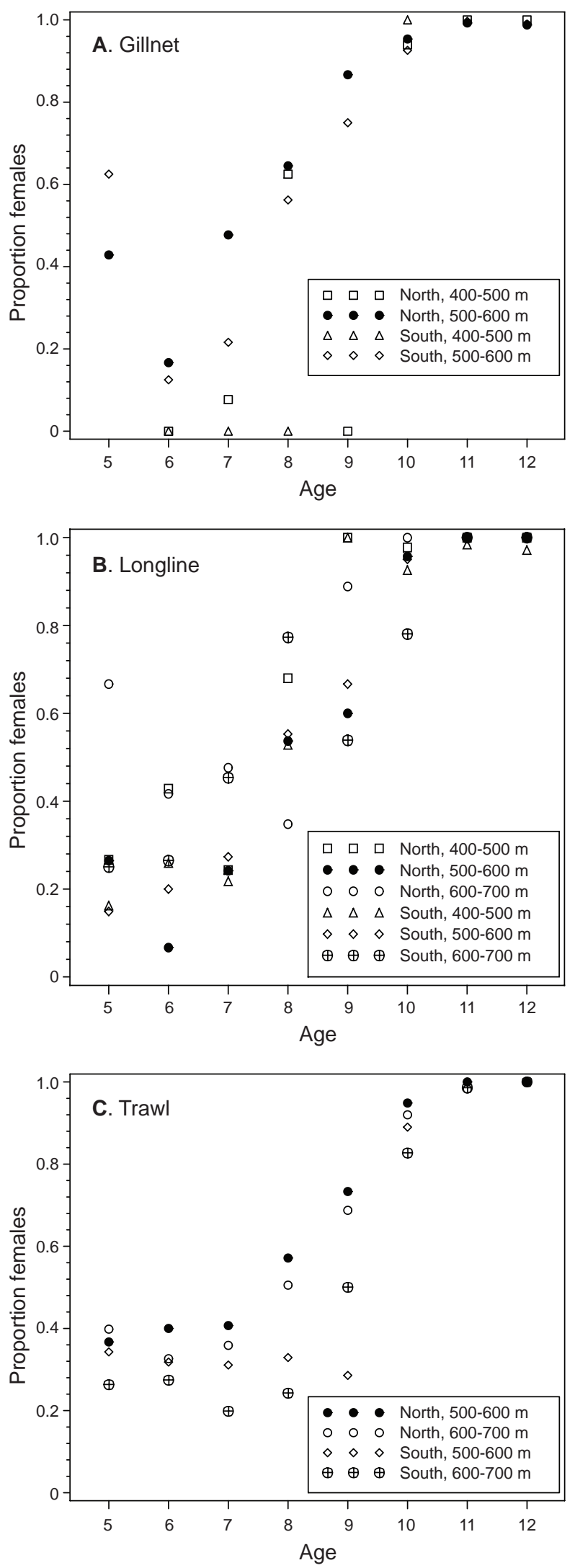

Fig. 8. Proportions of females-at-age in catches of Greenland halibut from A) gillnet, B) longline and C) trawl. the data showed that the mean length changed during the time period, and these changes could be due to changes in mean depth of the settings (Høines and Korsbrekke, MS 2001). Bowering and Nedreaas (2000) stated that mean individual size in trawl catches increased below $500 \mathrm{~m}$, peaked and then declined, which our findings confirms. The largest fish were found in the southern part of the area and, in the corresponding age groups, the proportion of females was high. This is in accordance with earlier work in this area, because the most important area for mature fish is found between Norway and Bear Island (Albert et al., 2001b), i.e. the southern part of our survey area. Therefore, we would expect the largest fish to congregate in this area. In the younger age groups males dominated, but in these age groups the highest proportion of females was found in the northern area. Catches from gillnets showed the same pattern, but this pattern was not so evident in the trawls. Dominance of females in the largest and oldest part of the stock is due to higher natural mortality for males (Kovtsova and Nizovtsev, MS 1985; de Cardenas, MS 1996).

The analyses also showed that immature fish were smaller than mature fish in all gears and age groups. One probable explanation for the fact that immature Greenland halibut are smaller than mature individuals is that only those that grow fast and reach a given size are maturing. Mature individuals may generally have a higher growth rate than fish that do not ripen, thus the mature fish in each age group are always the larger ones. The survey area only covers the larger individuals from the immature portion of the Greenland halibut population, since the juveniles are distributed further north and east (Smirnov, 1995; Albert and Høines, 2003; Albert et al., 2001a). When growing to the adulthood, the larger individuals migrate to the slope area between Norway and Spitsbergen (Godø and Haug, 1987; Albert et al., 2001a), and this migration to the spawning area may be a continual process starting long before the fish is actually mature. Consequently individuals that are immature reach the spawning area and are mixed together with the mature part of the stock. Another probable cause is that Greenland halibut are not necessarily ripe and spawn every year (Fedorov, 1971), which is causing problems in the determination of maturity stage, i.e. misclassifying mature fish as immature. Generally the largest number of misclassification of smaller fish using macroscopic determination of maturity is between early maturing and resting stages (Morgan et al., MS 2001). Our data were too sparse to go further into these questions. 
TABLE 5. Type III analysis of effects for the models predicting female proportion.

\begin{tabular}{|c|c|c|c|c|c|}
\hline Model & $R^{2}$ & Effect & $d f$ & $\begin{array}{c}\text { Wald } \\
c^{2}\end{array}$ & $P$ \\
\hline \multirow[t]{3}{*}{ Longline $^{1}$} & 0.2335 & Age & 7 & 234.89 & $<0.0001$ \\
\hline & & Depth & 2 & 2.88 & 0.2375 \\
\hline & & Area & 1 & 0.34 & 0.5581 \\
\hline \multirow[t]{3}{*}{ Gillnet } & 0.3617 & Age & 7 & 389.48 & $<0.0001$ \\
\hline & & Depth & 1 & 5.65 & 0.0175 \\
\hline & & Area & 1 & 10.17 & 0.0014 \\
\hline \multirow[t]{3}{*}{ Trawl } & 0.3502 & Age & 7 & 439.86 & $<0.0001$ \\
\hline & & Depth & 1 & 10.05 & 0.0015 \\
\hline & & Area & 1 & 46.62 & $<0.0001$ \\
\hline
\end{tabular}

${ }^{1}$ Due to significant over-dispersion the covariance matrix was rescaled (multiplied with 2.02616).

\section{Acknowledgements}

The authors thank anonymous reviewers for valuable comments, which have improved the manuscript significantly.

\section{References}

ALBERT, O. T., and Å. S. HØINES. 2003. Comparing survey and assessment data: Consequences for stock evaluation of Northeast Arctic Greenland halibut. Sci. Mar., 67 (Suppl. 1): (in press).

ALBERT, O. T., E. M. NILSSEN, K. H. NEDREAAS, and A. C. GUNDERSEN. 2001a. Distribution and abundance of juvenile Northeast Arctic Greenland halibut (Reinhardtius hippoglossoides) in relation to survey coverage and physical environment. ICES J. Mar. Sci., 58: $1053-1062$.

Albert, O. T., E. M. Nilssen, A. STEnE, A. C. GUNDERSEN, and K. H. NEDREAAS. 2001b. Maturity classes and spawning behaviour of Greenland halibut (Reinhardtius hippoglossoides). Fish. Res., 51: 217-228.

BOWERING, W. R., and W. B. BRODIE. 1995. Greenland halibut (Reinhardtius hippoglossoides). A review of the dynamics of its distribution and fisheries off eastern Canada and Greenland. In: Deep-Water Fisheries of the North Atlantic Oceanic Slope, A. G. Hopper (ed.). Northwest Atlantic Treaty Organization Advanced Science Institutes Series. Boston, USA. Kluwer Academic Publishers, p. 113-160.

BOWERING, W. R., and K. H. NEDREAAS. 2000. A comparison of Greenland halibut (Reinhardtius hippoglossoides, Walbaum) fisheries and distribution in the Northwest and Northeast Atlantic. Sarsia, 85: 61-76.

BOWERING, W. R., and K. H. NEDREAAS. 2001. Age validation and growth of Greenland halibut (Reinhardtius hippoglossoides (Walbaum)): A comparison of populations in the Northwest and Northeast Atlantic. Sarsia, 86: 53-68.

DE CARDENAS, E. MS 1996. The females ratio by length as an indicator of sexual differences in mortality of Greenland halibut (Reinhardtius hippoglossoides) at ages 8+. NAFO SCR. Doc., No. 35, Serial No. N2710, 10 p.

FEDOROV, K. Y. 1971. Zoogeographic characteristics of the Greenland halibut (Reinhardtius hippoglossoides, Walbaum). J. Ichthyol., 11: 971-976.

GODØ, O. R., and T. HAUG. 1987. Migration and recruitment to the commercial stock of Greenland halibut, Reinhardtius hippoglossoides (Walbaum), in the Svalbard area. FiskDir. Skr. Ser. HavUnders., 18: 311328.

GODØ, O. R., and T. HAUG. 1989. A review of the natural history, fisheries and management of Greenland halibut (Reinhardtius hippoglossoides) in the eastern Norwegian and Barents Seas. ICES J. Cons., 46: 62-75.

GODØ, O. R., K. RANDA, and O. M. SMESTAD. MS 1984. Preliminary report of the Norwegian groundfish survey at Bear Island and West Spitsbergen in the autumn 1983. ICES C.M. Doc., G:46, 18 p.

GUNDERSEN, A. C., O. S. KJESBU, and K. H. NEDREAAS. 1999. Fecundity of Northeast Arctic Greenland halibut (Reinhardtius hippoglossoides). J. Northw. Atl. Fish. Sci., 25: 29-36.

HØINES, Å. S., and K. KORSBREKKE. MS 2001. Some aspects of a time series of longline catch per unit of effort data for Greenland halibut (Reinhardtius hippoglossoides). NAFO SCR Doc., No. 119, Serial No. N4507, 12 p.

HUSE, I., A.C. GUNDERSEN, and K. H. NEDREAAS. 1999. Relative selectivity of Greenland halibut (Reinhardtius hippoglossoides, Walbaum) by trawls, longlines and gillnets. Fish. Res., 44: 75-93.

HYLEN, A., and K. H. NEDREAAS. 1995. Pre-recruit studies of the North-East Arctic Greenland halibut stock. In: 
Precision and relevance of pre-recruit studies for fishery management related to fish stocks in the Barents Sea and adjacent waters. A. Hylen (ed.). Proceedings of the sixth IMR-PINRO Symposium, Bergen, 14-17 June 1994. Institute of Marine Research, Bergen, Norway, p. 229237.

ICES. MS 2001. Report of the Arctic Fisheries Working Group. ICES C.M. Doc., No. ACFM:19, 390 p.

KOSIOR, A. 1975. Polish investigations on Greenland halibut in the northeast Arctic in 1973. Ann. Biol., 30: 172173.

KOVTSOVA, M. V., and G. P. NIZOVTSEV. MS 1985. Peculiarities of growth and maturation of Greenland halibut of the Norwegian-Barents Sea stock in 1974-1984. ICES C.M. Doc., No. G:7, 16 p.

MORGAN, M. J., W. R. BOWERING, A. C. GUNDERSEN, Å. S. HØINES, B. MORIN, O. V. SMIRNOV, and E. HJØRLEIFSSON. MS 2001. Comparative analyses of Greenland halibut (Reinhardtius hippoglossoides) maturation for populations throughout the North Atlantic. NAFO SCR. Doc. No. 116, Serial No. N4504, 13 p.

NEDREAAS, K. H., A. V. SOLDAL, and Å. BJORDAL. 1996. Performance and biological implications of a multi-gear fishery for Greenland halibut (Reinhardtius hippoglossoides). J. Northw. Atl. Fish. Sci. 19: 59-72.

ONA, E. and O. R. GODØ. 1990. Fish reactions to trawling noise: the significance for trawl sampling. ICES Rapp. Proc. Verb., 189: 159-166.

RANDA, K., and O. M. SMESTAD. MS 1982. The Norwegian groundfish survey at Bear Island and west Spitsbergen in the autumn 1981. ICES C.M. Doc., No. $\mathrm{G}: 42,17 \mathrm{p}$.

RANDA, K., and O. M. SMESTAD. MS 1983. Preliminary report of the Norwegian groundfish survey at Bear Island and West Spitsbergen in the autumn 1982. ICES C.M. Doc., No. G:34, 19 p.

SMIRNOV, O. V. 1995. Dynamics of Greenland halibut recruitment to the Norwegian - Barents Sea stock from 1983-1993 trawl survey data. In: Precision and relevance of pre-recruit studies for fishery management related to fish stocks in the Barents Sea and adjacent waters. A. Hylen (ed.). Proceedings of the sixth IMR-PINRO symposium, Bergen 14-17 June 1994. Institute of Marine Research, Bergen, Norway, p. 239-242.

WHITEHEAD, P. J. P., M.-L. BAUCHOT, J.-C. HUREAU, J. NIELSEN and E. TORTONESE (eds.). 1986. Fishes of the North-eastern Atlantic and the Mediterranean. UNESCO, Paris, France, 1473 p. 